Rubric 1. TECHNOLOGIES AND PROJECTS

Field - Transport and Transport \& Logistics Systems

DOI 10.17816/transsyst2021735-29

(C) R. Özbek, M. Y. Çodur

Erzurum Technical University

(Erzurum, Turkey)

\title{
COMPARISON OF HYPERLOOP AND EXISTING TRANSPORT VEHICLES IN TERMS OF SECURITY AND COSTS
}

\begin{abstract}
Technological developments have increased the possibilities, comfort, reliability, and speed of the transportation network in the world. Today, various transport vehicles try to meet the speed, economy, and safety demands of passengers. However, as the passengers' demand increase depending on the population, the requirement for innovation in this field increases. Various studies have been carried out to determine the benefit-cost ratio of Hyperloop, an alternative developed to meet the speed requirement in this respect. The decision to build the Hyperloop anywhere else in the world depends on the system's characteristics, such as sustainability, economy, safety, and response to passenger demands. In this study, Hyperloop and existing systems were compared with comfort, safety, and cost considering these criteria. It was focused on the commercial planes, Maglev, and high-speed train features, as they are similar to Hyperloop in these comparisons. Based on the relevant data, it has been reached that the Hyperloop system could prevent it from becoming a widespread public transport vehicle because of its low passenger capacity and expensive construction and operation.
\end{abstract}

Key words: feasibility, g-force, high-speed train, Hyperloop, Maglev, pressure, security.

\section{INTRODUCTION}

The movement of people and goods has increased day by day with the growth of the world population. This increase has led to the development of technology toward increasing transportation capacity and speed. However, developing technologies are in a race not only in speed but also in comfort, safety, and energy efficiency. The latest and most prominent of these technological advances is Hyperloop. Hyperloop was introduced to a high-speed tube transportation system supported by Elon Musk in 2013. There have been many studies from investors and student initiatives in many countries after it was announced the transportation concept in the Hyperloop Alpha report by Elon Musk. Currently, there are 8 companies in 6 countries (USA, China, Canada, Netherlands, Spain, Poland) working on Hyperloop, over 50 university teams, and over 1000 employees involved in R\&D [1]. In this respect, this study was written in order to present the advantages and disadvantages of existing systems and Hyperloop and to contribute to the feasibility studies. 


\section{HYPERLOOP HISTORY}

Different infrastructures and projects had been presented for a tube transportation idea since 1799 before Elon Musk. The idea of moving freights through cast-iron pipes using air pressure was proposed by George Medhurst in 1799. A railway station was built in London for the purpose of transporting passengers with a pneumatic system in 1844. In the mid-1850s, more pneumatic railroads were built in various places such as Dublin, London, and Paris. Crystal Palace atmospheric railway was constructed in the mid-1860s in South London. New York's oldest subway, the Beach Pneumatic Transit, which served from 1870 to 1873 , was developed by Alfred Ely Beach. This underground pneumatic public transport system had a stop in the basement and a one-car shuttle that used compressed air to move. Pneumatic tube systems became common in use for delivering mail and other messages in most major cities in the late 19th century. Some of them are still used today in banks, hospitals, and factories. A train that could travel on magnets in a vacuum-sealed tunnel was designed in 1910 by American rocket pioneer Robert Goddard. The project, which was planned to travel from Boston to New York in 12 minutes, was never realized due to budget constraints and politics. In the early 1990s, a vacuum train system was designed to reduce the travel time to 45 minutes between New York and Boston by researchers at MIT. In the early 2000s, a pneumatic-and-maglev train consisting of car-sized capsules in elevated tubes was designed by ET3 transport company. The food tubes project concept was designed to carry food by traveling 60 miles per hour underground in 2010. If it was built in England, which would have cost $\$ 8$ million per mile. A concept called Hyperloop that using magnetic rails in a vacuum-sealed tunnel with a capacity of 28 passengers in each capsule was proposed by Elon Musk in 2013. A submarine railway project that would run at a theoretical speed of $1,240 \mathrm{mph}$, much faster than Musk's Hyperloop concept was proposed by researchers from the Chinese Academy of Sciences in 2017 [2]. The underwater tests were determined reactions to waves and whether any movements of the Hyperloop allow the "pods" to travel through the tube safely and at sufficient speed by the Netherlands Institute of Marine Research (Marin) in 2019 [3].

Hyperloop first appeared as a vactrain idea by inventor and rocket scientist Robert Goddard in 1904, when he was a first-year physics student at the Worcester Polytechnic Institute in Massachusetts. He presented his idea to Scientific American in 1906. Later, this idea of transportation was taken up by the American physicist Robert M. Salter in 1972-1978 and most recently by Elon Musk in 2013. There are other initiatives on this topic, but this is the most similar attempt to Musk's proposal. Salter's proposals also include estimates of the project construction and the transportation charges to passengers to generate revenue and offset costs for 1972-1978. It was estimated that the transportation system between New York and Los Angeles would be between $\$ 250-500$ billion 
in 1978 (between \$1 trillion and \$2 trillion, according to 2019 inflation). It was suggested an initial collaboration with the military to create and use these underground tunnels to transport resources (transport materials such as gas, water, and electricity, and they would pay for usage with fees) across the United States to pay for the project by Salter. It was estimated that $\$ 50$ would pay for each passenger (the US \$200 in 2019), and $\$ 5.3$ billion will be gained annually by carrying 300,000 people from 100 passengers per vehicle per day in the project. However, this project was never built in actual life because of public and cost policies [4].

There have been many feasibility studies of many entrepreneurs for market search in several countries of the world since it was published a white paper by Elon Musk. It was planned to build a $65 \mathrm{~km}$ Hyperloop line that could help revive the 21st-century Silk Road between Russia and China, which would be cost about $\$ 1.5-2.3$ billion, in 2017 [5]. It was planned a $150 \mathrm{~km}$ system between Abu Dhabi and Dubai which would reduce to 12 minutes' travel time, would be cost about $\$ 20$ to $\$ 40$ million per $\mathrm{km}$, by the Hyperloop Transport Technology company in 2019 [6,7]. The Hyperloop system which would reduce to 25 minutes travel time to be ready by 2029 for the $148 \mathrm{~km}$ corridor between Mumbai-Pune has been negotiated by Hyperloop One company and India's government officials $[8,9]$. The Netherlands has become one of the important representatives of Hyperloop in Europe [10] (Tab. 4).

HyperPoland company, which is interested in Hyperloop technology in Poland, presented the idea of realizing Hyperloop in 3 steps. In the first step, it has been planned to implement the hybrid system known as Magrail, which would increase the speed of the train to $300-415 \mathrm{~km} / \mathrm{h}$ with the passive magnetic lift pod, which would be positioned in the middle of the existing traditional train tracks, in 5-8 years. The cost has been estimated to be between 6 million and 8 million Euros per kilometer, excluding additional structures. In the second step, the Hyperrail system, which has been planned to reach a speed of 600-1000 $\mathrm{km} / \mathrm{h}$, has been aimed to be implemented by closing Magrail with vacuum tunnels. In the third and last step, it has been planned to realize the Hyperloop that the special infrastructure surrounded by vacuum tubes that would enable acceleration to $1200 \mathrm{~km} / \mathrm{h}$ [11].

\section{HIGH-SPEED TRAIN HISTORY}

Japanese Tokaido Shinkansen, which was opened in 1964 between Tokyo and Osaka, is considered the world's first modern and commercial high-speed train. France was the first country to introduce the first commercial HSR line (for passengers) in Europe in 1981 after a few diverse initiatives. The system used in France, unlike the Japanese system, is fully compatible with the existing railway network, so the use of the same standard dimensions reduced construction costs. Germany was the next country to launch HSR with the 
InterCity Express (ICE) connecting Hannover and Würzburg, beginning service in 1991. Spain integrated French and German technology with a system akin to Japanese technology between Madrid and Sevilla by opening the Alta Velocidad Española (AVE) in 1992 [12].

\section{MAGLEV HISTORY}

Maglev technology was first patented in 1969 by two American scientists, James R. Powell and Gordon T. Danby. Germans and Japanese spearheaded further development in the early 1970s [13]. In the early 1970s, Germany created the Transrapid train, which was the world's first Magnetic Levitation rail system. The concept of this system had patented in 1934 by Hermann Kemper in addition, there are many scientific patents and studies that contribute to the development of Maglev in many parts of the world [12,14]. Transrapid train technology is based on the attractive electromagnetic forces (EMS) levitation of trains over ferromagnetic guideways with an apart levitation and guidance technology. Shanghai Pudong Airport Transrapid, which has been operating in China since 2003, is the only commercial line using transrapid technology [12]. In 1984 the first commercial Maglev line was opened in Birmingham, England, but was closed in 1995 as it was deemed unreliable[14,15]. Japan, developing High Speed Surface Transport (HSST) technology based on EDS technology in 1972, opened its first commercial line HSST Linimo in Nagoya in 2005. After HSST Limino, the second commercial line, Incheon Airport Maglev, was opened in South Korea. The desire to develop a simplified and more economical Maglev has led the USA to build the Inductrack, a repulsive force electrodynamic magnetic levitation system (EDS) that has never been a reality. Inductrack is a cheaper EDS besides it has auxiliary wheels support in situations that may cause decreased levitation, such as system failure or low speed. A new dynamic superconducting EDS, the SCMAGLEV, was also designed by Japan. In this case, the train is fitted with some superconducting magnets in its bogies, which enable the vehicle to raise about $10 \mathrm{~cm}$ above the guides and use an asynchronous ironless motor to propel it. The Chuo Shinkansen, the world's first commercial SCMAGLEV intended to span the Tokyo-Nagoya distance, has been under construction since 2014 and was projected to open in 2027, extending to Osaka in 2045 [12].

\section{MAGLEV SYSTEM}

Hyperloop is designed magnetism-based and inside a vacuum-sealed tube to increase the efficiency of Maglev and its derivatives. Maintenance costs and energy losses due to friction are low as both systems because of based on magnetism. Maglev technology is based on 3 basic principles; The principle of magnetic levitation, lateral guidance, and repulsion (Fig.1). 


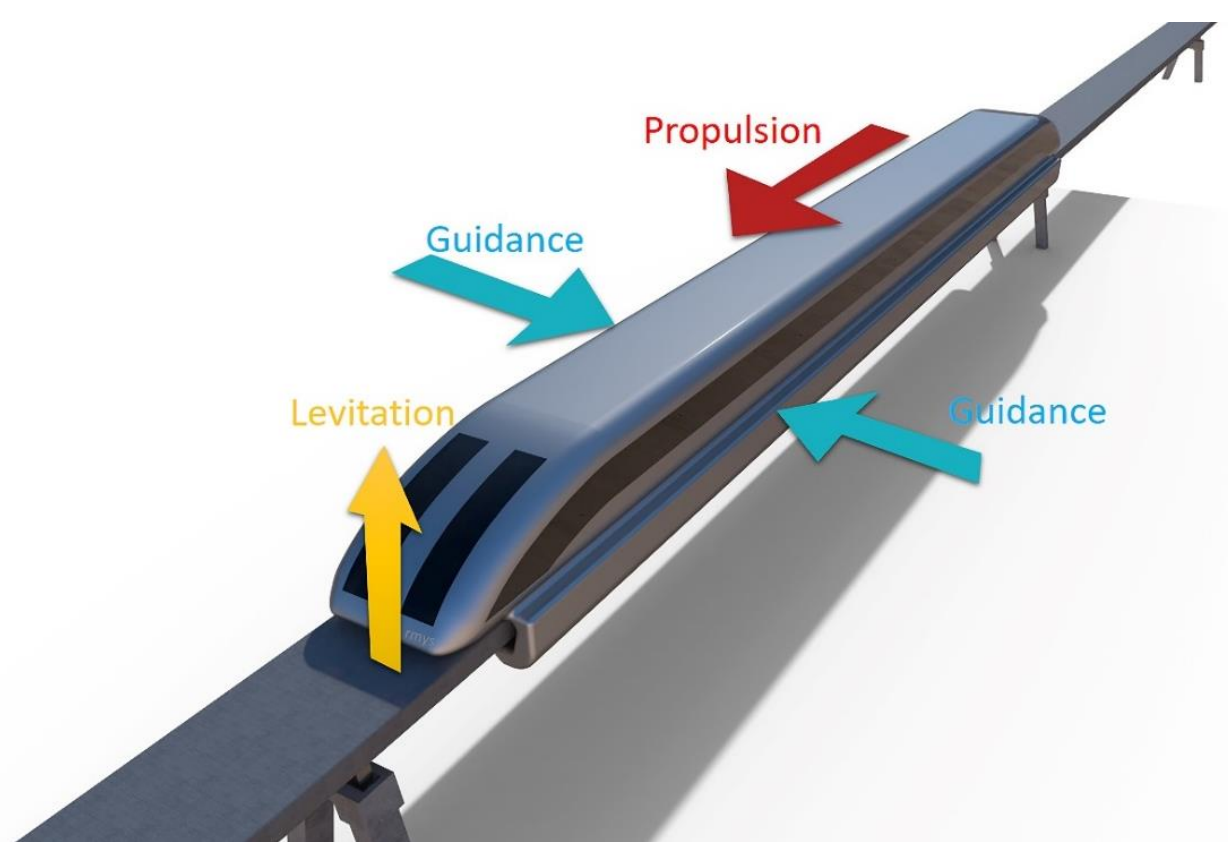

Fig. 1. Maglev technology principle(redraw) [16]

The Maglev system can be classed as an electrodynamic suspension (EDS) system, an electromagnetic suspension (EMS) system, a permanent magnet electrodynamic suspension system (PM-EDS), or a hybrid electromagnetic suspension system (HEMS), depending on the mechanism employed to achieve levitation [17]. EDS and EMS, which are two fundamental levitation technologies, are focused on in this study (Fig. 2).

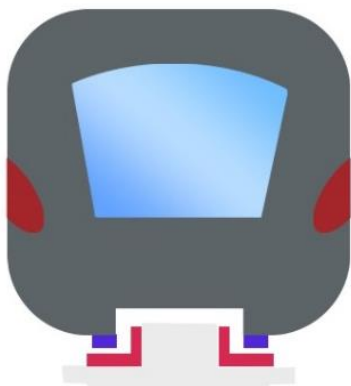

Electrodynamic

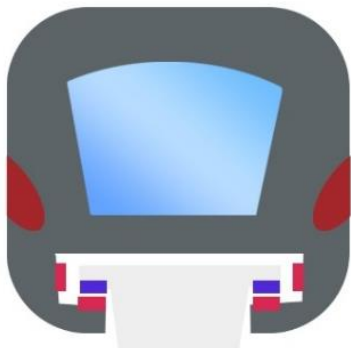

Electromagnetic

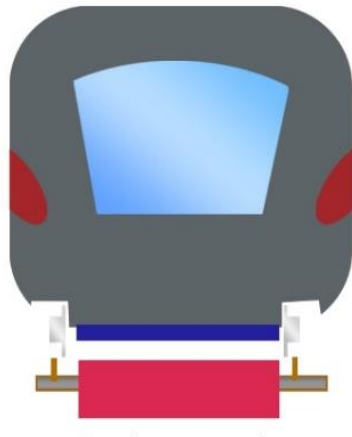

Inductrack

Fig. 2. Levitation techniques

EMS system employs magnetic attractive forces for accomplishing levitation. Magnetic attractive forces occur as a result of interaction between the guideway and the on-board electromagnets assembled below the guideway, as shown in Fig. 3. Standard electromagnets are used, which need an electrical power source to be active. It occurs $10-15 \mathrm{~mm}$ thick levitation thanks to magnetic attractive forces. However, as the speed of the train increases, it 
becomes difficult to control the air gaps, which leads to a lack of stability. The advantage of EMS is that the train can stay in the air in any situation, even at zero speed. This results in making the travel more comfortable for the passengers. The EMS system is used in the Shanghai Maglev, Korean UTM, Japanese HSST, and The German Transrapid TR09 [12,17,18].

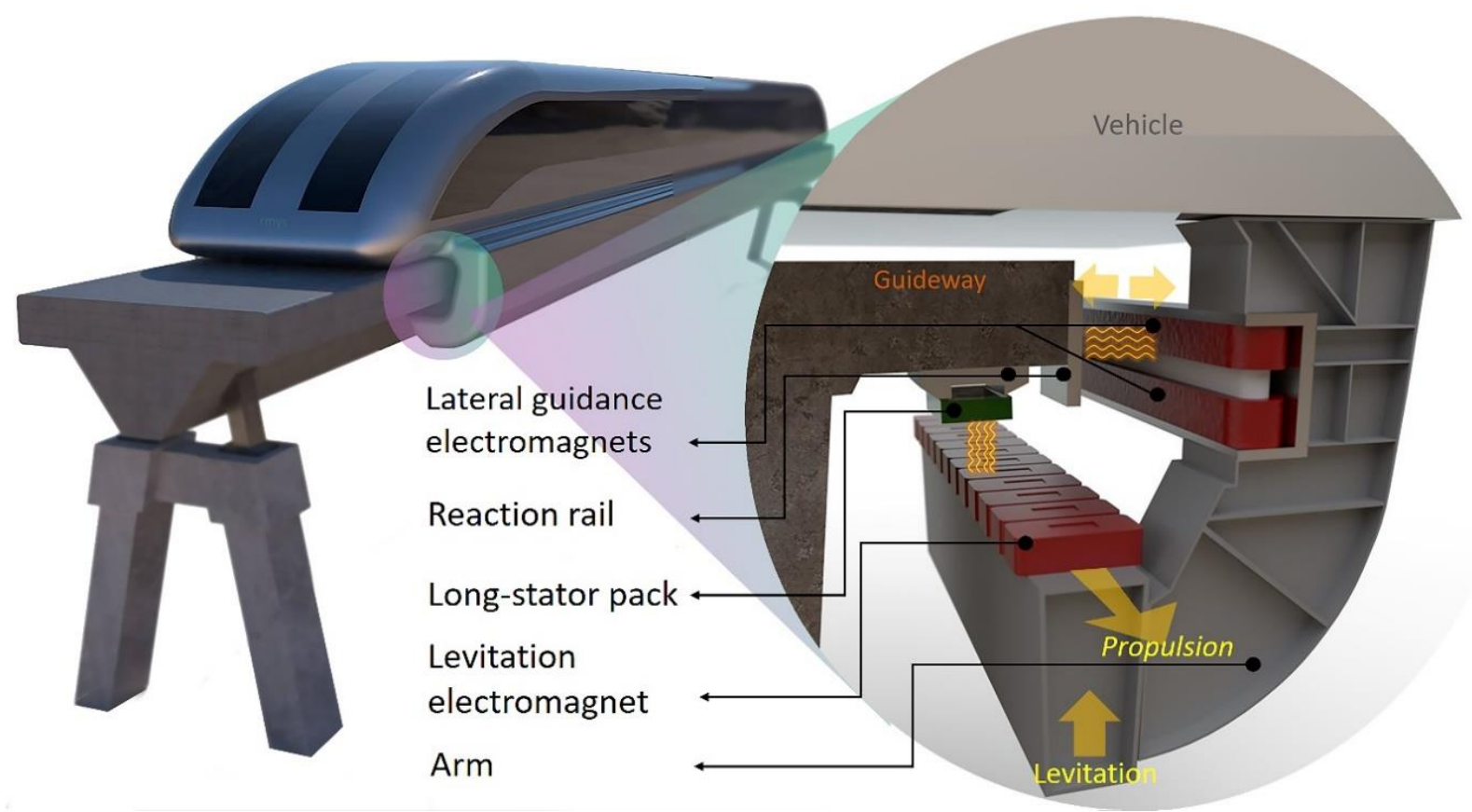

Fig. 3. Maglev EMS system modeling

EDS system uses magnetic repulsive forces to induce levitation, as shown in Figure 4. This thrust can lift the vehicle to $10 \mathrm{~cm}$. It is used superconducting magnets (SCMs) in the EDS system. The powerful magnetic field created by superconducting magnets can pass through the train, cause disturbing passengers. These magnets raise the cost of the system. The system needs rubber tires until it reaches a lift-off speed. In the electrodynamic propulsion system. The levitation principle is provided by the coils placed on the sides of the guideway and the superconducting magnets on the vehicle. When the Maglev train passes at a high speed about a few $\mathrm{cm}$ below the center of these coils, an electric current is induced into the coils and the Maglev train is lifted into the air, allowing it to move. Lateral guidance principle; It is a necessary system to prevent lateral displacement Electro pulling lateral guidance function in electrodynamic thrust system, lateral guidance function is provided by coils placed on both sides of the guideway $[17,18]$. 


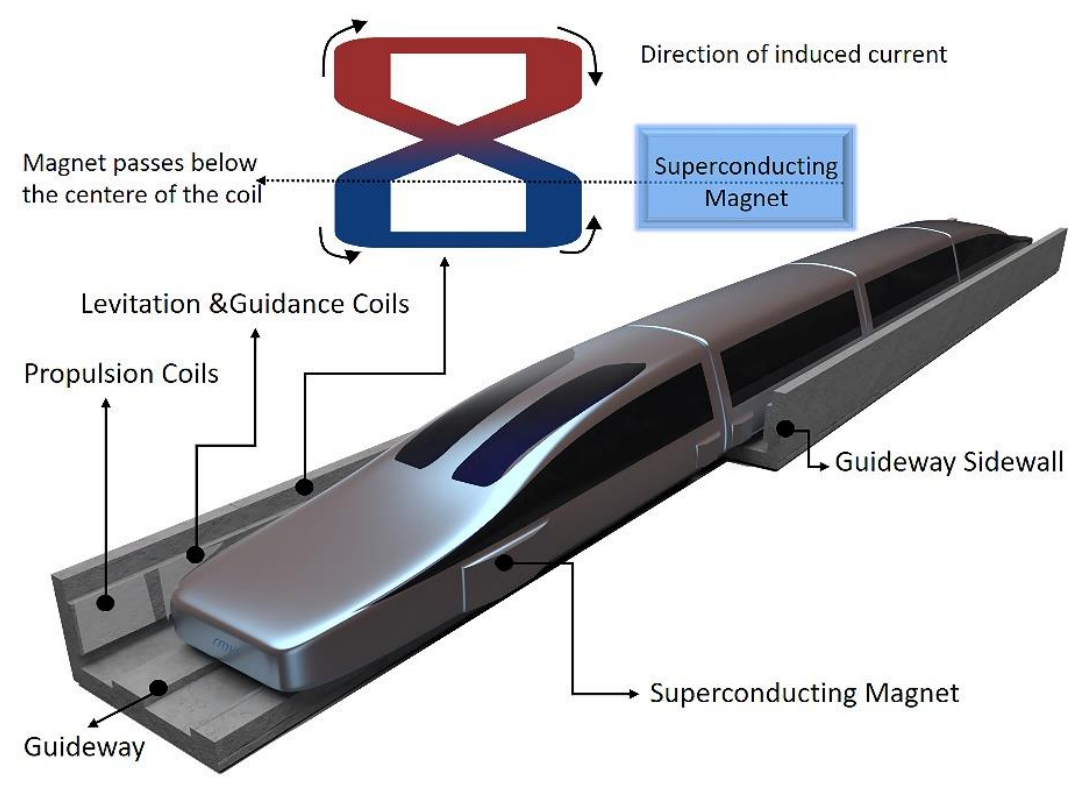

(a)

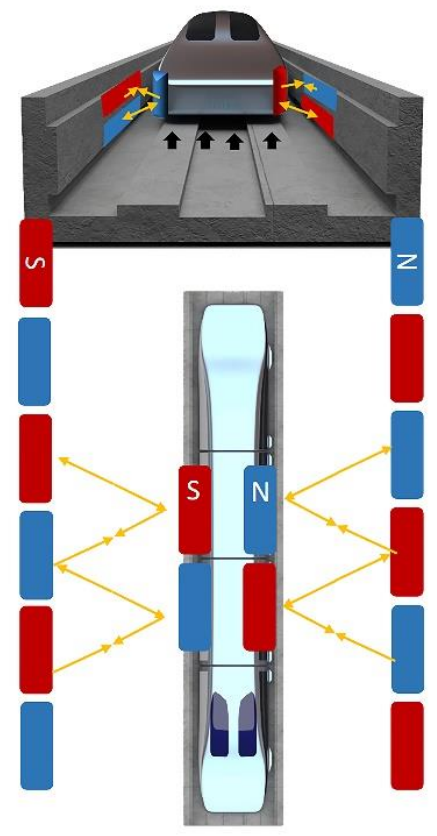

(b)

Fig. 4. Maglev EDS system modeling (general description)

The forward movement and braking of the train are the same as the electric motor in the operating principle. The motor windings lined up along the guideway function as a stator and the electromagnets on the vehicle act as a rotor. The alternating current supplied to the motor windings creates magnetic flux that moves the train. The speed of maglev trains is adjusted depending on the frequency of the alternating current and is realized by creating a magnetic force in the opposite direction of train braking [18].

\section{HYPERLOOP SYSTEM}

Hyperloop comprises capsules that create an air cushion with the help of compressors and motors in a pressure-relieved tube, reducing friction with the "air hockey" principle and providing fast transportation at maximum efficiency. It is designed in two types, cargo, and passenger. It will be built on poles that ensure the continuity and smoothness of the line at various heights from the ground. It is aimed to provide maximum energy gain by covering the top surface of the tubes with solar panels. Tubes will be made of steel material with a diameter of 3.3 meters. The surface of the tubes will be covered with solar panels that will provide both the production and storage of the energy to be used in the movement of the capsules [19]. It was stated that setting up the system on pylons would reduce the land costs (Fig. 5). However, it will require some legal regulations regarding the use of air rights. Lawyers in the USA and Dubai discuss the legal infrastructure on this issue [20]. 


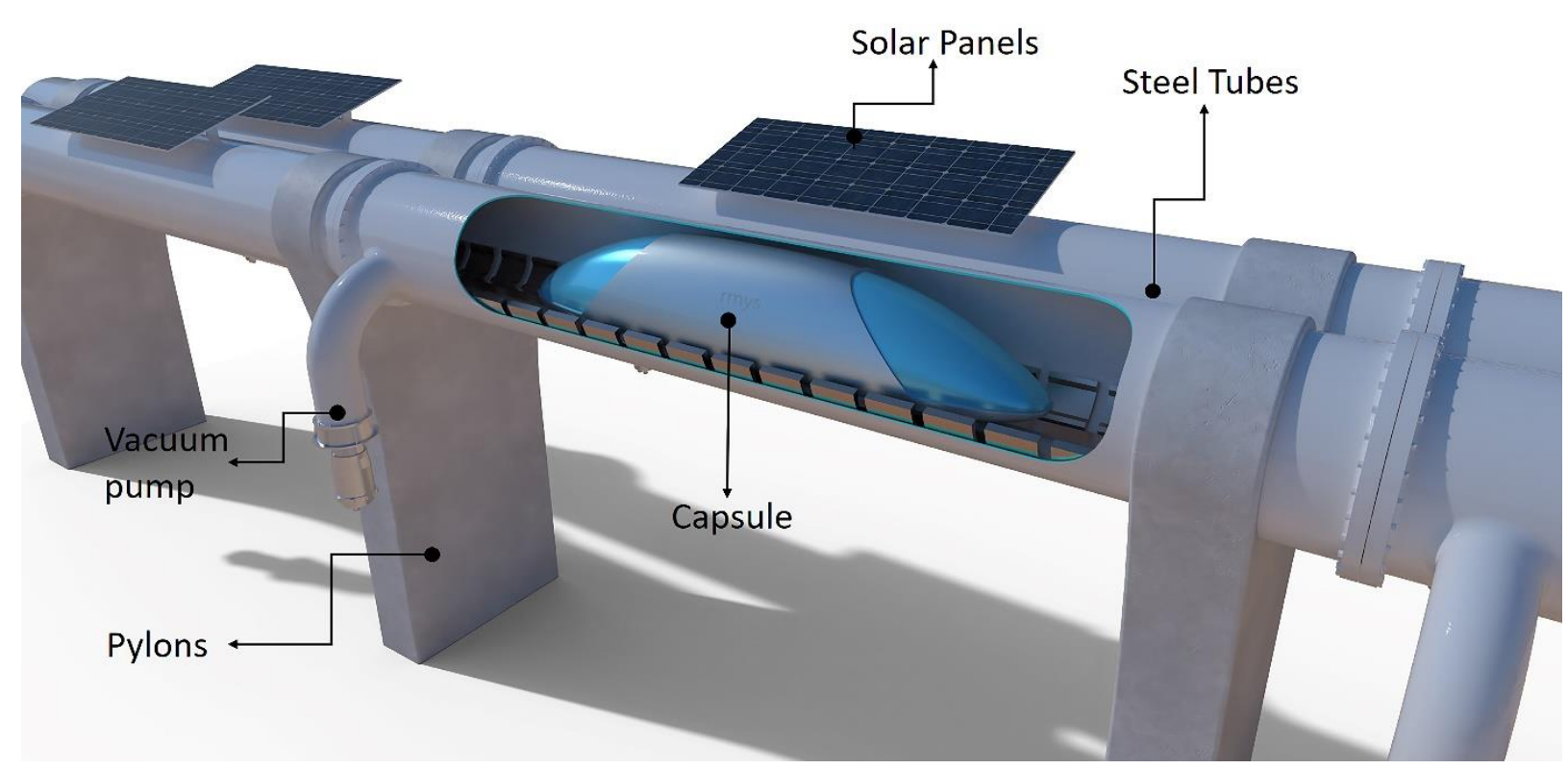

Fig. 5. Hyperloop 3D predictive modeling

In the original concept of the Hyperloop Alpha, a concept in which capsules float on a layer of compressed air has been proposed [21]. It is not yet known exactly what will happen in practice. Hyperloop Transportation Technology company talked about the Inductrack system, which it considers safe to give the same effect. In this method, magnets are placed under the capsules in a Halbach array. The magnetic force of the magnets is focused on one side of the array, while the field on the opposite side is nearly entirely cancelled out. As the capsules travel past electromagnetic coils implanted in the road, these magnetic fields allow capsules to float. The linear motors' thrust propels the capsules forward. Hyperloop One also employs a passive magnetic levitation technology, in which permanent magnets on the capsule's side repel a passive track, with the capsule's speed being the only source of energy. To aid the passage of the capsules, the air pressure in the tunnels is decreased using air pumps in both systems. Because low air pressure significantly lowers friction, relatively a little quantity of electricity is necessary to reach the greatest speeds [22].

\section{SECURITY}

Security is the most noticeable issue for Hyperloop. In case of any malfunction in the system, passengers will be at risk. Therefore, the engineering reliability of Hyperloop has been discussed in subjects such as emergency interventions, g-force, structural behavior during earthquakes.

The security performance of a transportation system is evaluated in two ways; interior security and exterior security. Interior security is concerned with 
the risks of damage from the system itself. Exterior security is concerned with the potential risks of accidents caused by its environment [23]. This study has been included g-force and pressure in interior security, and earthquake factor in exterior security.

When Hyperloop is evaluated in terms of route safety, it is not affected by weather events, unlike other means of transportation. However, it is vulnerable to human influences, as with highways and rail routes. Hyperloop's high-value property may make it a target of potential terrorist attacks along the route. Additional measures should also be taken regarding this [24]. In the Hyperloop Alpha report, it is stated that the security precautions to be taken at the station will be similar to airports [19].

There is a lithium-ion battery system in the capsules to complete the travel in case of potential power outages. Also, it is claimed that the travel will be completed without requiring additional power after the pod moves in Hyperloop Alpha [19].

When an emergency occurs in a capsule on the road, the capsules are allowed to get help by contacting the station. It was stated that there were hostesses and first aid equipment in the capsules during the travel. When an emergency is encountered in an aircraft, there is a waste of time in returning the aircraft to the runway because of implementing many protocols. Therefore, it is claimed that Hyperloop can respond faster in emergencies than aircraft. However, no information has been given about how the first aid team will reach and how the communication will be with the other capsule in the depressurized tube, and how this will affect the other capsules traveling.

A similar system has also been the subject of the Maglev train. If the power from the public grid fails while the vehicle is running, only the propulsion system (motor) will not work because the vehicle levitation and guidance systems as well as all onboard equipment are powered by on-board batteries, so the vehicle continues to move forward with its current momentum. If the next station is too far away, the vehicle will automatically brake to stop at 'safe stopping area' planned for this purpose along the route [13].

NASA has calculated Hyperloop's emergency stop distances in case of system failure. Assuming that the capsules are launched every 30 seconds at a maximum speed of $295 \mathrm{~m} / \mathrm{s}(660 \mathrm{mph})$ with an acceleration of $0.5 \mathrm{~g}$ and that the front capsule can be stopped immediately, it has been concluded that a 30second advance is appropriate for stopping to prevent the collision [24].

\section{PRESSURE}

Hyperloop technology aims to reduce friction and increase energy efficiency and speed by depressurizing tubes with vacuum pumps. However, there are some security concerns. 
According to the Hyperloop Alpha report, low pressure will be created around $0.015 \mathrm{psi}$ (100 $\mathrm{Pa}, 0.75$ torr) of the in-tube pressure (approximately $1 / 6$ of the pressure on Mars or 1/1000 of the pressure on Earth) that will provide optimum airflow [19]. When this pressure value is placed in as shown in Eq. 1, it is seen that the pressure value of 100 Pascal corresponds to the flight from $32450 \mathrm{~m}$ above sea level (Eq. 2). This altitude is much higher than commercial airline flights $(10,000 \mathrm{~m})$.

$$
P=101325 x\left(1-2.25577 \times 10^{-5} h\right)^{5.25588}
$$

Where $\mathrm{p}=$ air pressure $(\mathrm{Pa})$ and $\mathrm{h}=$ height above sea level in meters $(\mathrm{m})$

$$
\begin{aligned}
& \left.100=101325 x\left(1-2.25577 \times 10^{-5} h\right)\right)^{5.25588} \\
& \mathrm{~h}=32450.438 \text { meters }
\end{aligned}
$$

Such low pressure can be difficult and costly to apply in large areas, especially in case of leakage [25].

Sudden pressure loss is a serious condition. The person can lose consciousness in a short time. The time between sudden pressure reduction and loss of ability to perform a beneficial activity is called "The Time of Useful Consciousness" or TUC. The action to be taken to correct the problem must be done before the TUC ends. Commercial aircraft routinely fly over distances of over 10,000 meters. TUC is less than one minute at these altitudes [26,27].

Passenger aircraft flying at 35,000 feet $(10,000 \mathrm{~m})$ without protection causes hypoxia (oxygen deficiency), lack of vision, and death because of physical changes in the human body. However, the reason passengers are unaffected by this is that the plane has a pressurized cabin [27]. This system is undoubtedly necessary for the Hyperloop, considering during travel in the depressurized tube and the pressure balancing processes for the evacuation at the stations. However, traveling in a low-pressure environment is a proven technology thanks to airplanes. Besides having Hyperloop autonomous driving, the pressure in the tube is planned to be kept under constant control. In the event of any pressure-related mishaps on the aircraft, the life of the passengers during the TUC period will depend on the skills and expertise of the pilots. In this respect, Hyperloop is more advantageous.

\section{EARTHQUAKE}

Earthquakes are dangerous for all structures. However, road geometry and vehicle design can increase or decrease the destructive effect of the earthquake. The long side of the Hyperloop and railways has a relatively weak-inertia compared to the short side. The weak inertia side is more easily damaged during an earthquake. It can lead to fatal consequences because of the vehicle in motion overturning more easily, the train derailment, or route destruction. 
Since Hyperloop is most similar to railways in terms of structure, it has the same disadvantages as railways during an earthquake. There is an existing technology used for earthquakes for high-speed trains and Maglev. This technology is suggested in Hyperloop [28]. The system is an early warning system that cuts off the train's power supply before seismic waves reach the train tracks to slow down or even stop the train as soon as possible during an earthquake. Two different seismographs are used on the Shinkansen train, positioned at regular intervals along the coastline and in transformers. This system succeeded in safely stopping the Shinkansen train, which traveled at an average speed of $320 \mathrm{~km} / \mathrm{h}$ in 2011, without derailment, in an earthquake of 8.9 magnitudes [29]. Some experts believe that this system is inadequate because even if the system works properly, considering the delay time of at least 26 seconds of the system. The train may get derailed or overturned, or crash into a collapsed building when an earthquake occurs directly underneath the area where the train is running at high speed [30].

The moving tipper pylons proposed by Hyperloop Alpha for on-the-road pods are aimed at both protecting the line and ensuring the safety of passengers by reducing the effects of an earthquake and thermal expansion [19]. In severe earthquakes, it is also possible to remotely control the emergency braking systems in the capsules [24].

\section{COMFORT}

Ride comfort is a complex concept that is affected by various stimuli such as temperature, acoustic noise, arrangement of the seat, visual stimuli, humidity, odor, vibrational, and changes according to the person [31]. There are several methods used to evaluate ride comfort. The evaluation of ride comfort in terms of vibration is an influential method and is directly related to vehicle dynamics performance. Ride quality depended on people's comfort evaluation includes not only the amount of movement but also the human interaction variables. Ride comfort is usually measured by the acceleration experienced by the passenger during the movement of the vehicle. Each organ in the human body has its own frequency ranges that are sensitive to vibration, so excessive exposure to vibration will reason disturbance and health issues. The human body is much more sensitive to vertical vibrations in the $4-8 \mathrm{~Hz}$ frequency range. While the stomach is negatively affected by the frequencies of $5-6 \mathrm{~Hz}$, the head and neck are disturbed by the frequencies of $20 \mathrm{~Hz}$. These frequency investigations incorporate weighted acceleration concepts to determine the comfort level based on ISO 2631-1. It is difficult to determine the ride comfort standard on a global scale due to the vibration characteristics of the vehicle, the differences in the vehicles stability, the country-specific quality standards of the railways and roads and the technological differences in each country [32,33]. 
Hyperloop is not expected to generate any external noise affecting the nearby population. Since the Hyperloop does not come into contact with the tube, the absence of vibration flow and low air pressure in the tube prevents the noise from the capsule from propagating. The noise of vacuum pumps is assumed to be negligible [23]. In addition, the absence of vibration provides comfortable driving for the passenger. It can be said that the Maglev train has the same characteristics for noise and smooth ride.

The approximately $3 \mathrm{~cm}$ thick steel pipe used in the malfunction of the Hyperloop is a distressful situation for claustrophobia patients (Fig. 6). Herbert Einstein, US University MIT's tunneling expert, has been advocated for claustrophobia patients that progressing through a closed windowless tube is tolerable to reach the goal faster [34]. However, it may vary dramatically in severity from person to person.

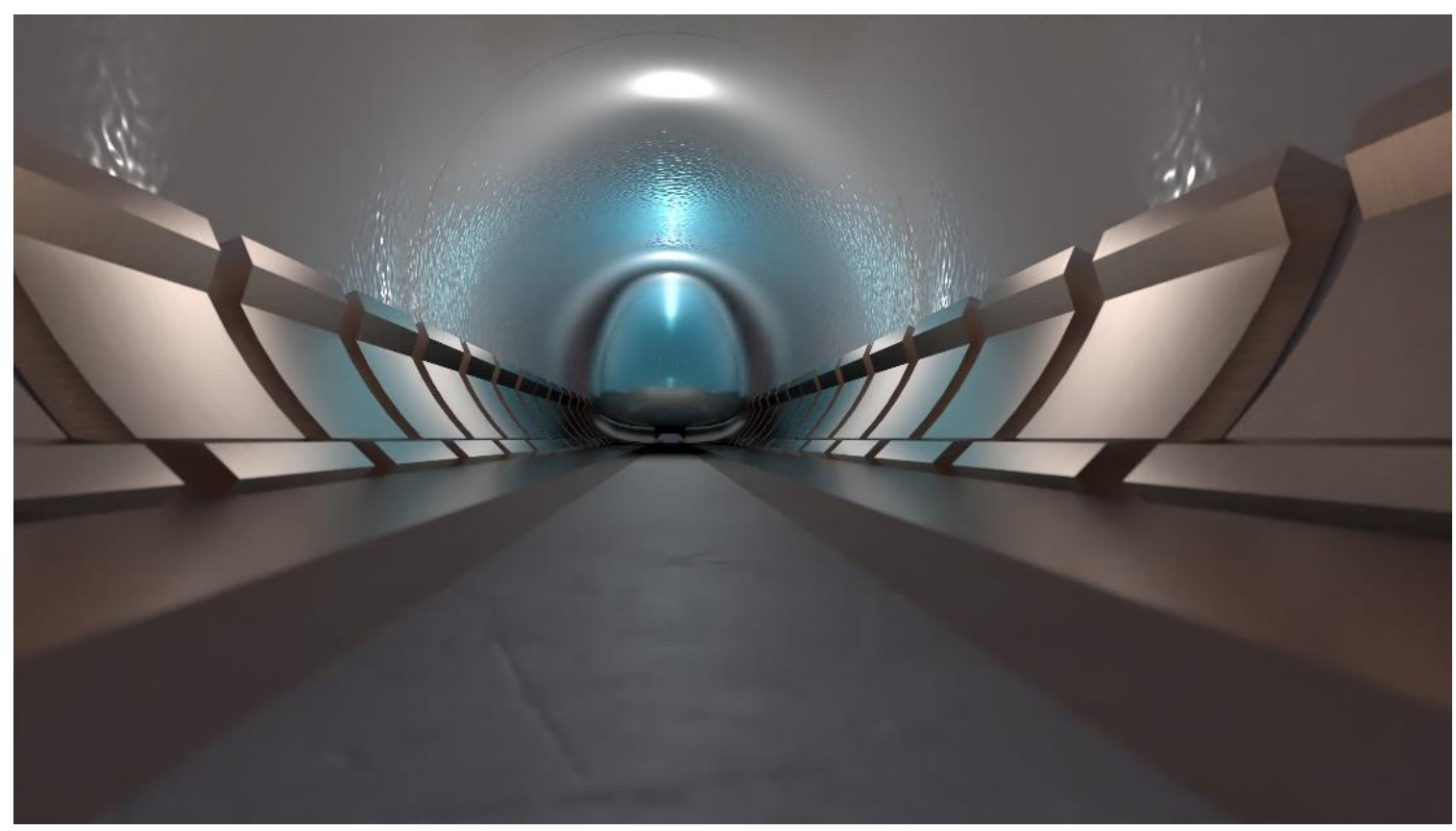

Fig. 6. Inside of the Hyperloop 3D modeling

It has been suggested that the lack of a window and focal point at which the human brain can detect the speed at high speeds can affect a person's balance, sensor, motor, and other nervous systems function [35]. Therefore, various solution suggestions have been presented on this issue. The Zoetrope technique, which was emerged in 1865, was introduced by Virgin Hyperloop One and Bjarke Ingels Group (BIG).

The pictures, each of which will be positioned 10 meters apart, are aimed to create an uninterrupted blurred view when the Hyperloop pods move fast enough [36]. Another technology proposed by the Hyperloop One company is electronic windows that show air temperature, speed, and time together with augmented reality images [37]. 
Lack of toilet has also been mentioned in some studies, but should not be a problem for most people traveling on trips less than an hour [24]. In addition, Maglev also has toilets for long-distance travel between cities, but not for short distances [13].

$\mathrm{G}$ force is a measure of comfort as well as safety in transportation. Passengers may die from internal bleeding without any physical injury during a collision due to g-force. The negative effect of the g-force on humans increases in direct proportion to the acceleration/deceleration. G-force occurs in 3 cases. Linear acceleration occurs when an object's speed increases and decreases without changing its direction in a straight line (occurs landing, taking off, braking, acceleration, deceleration). Radial acceleration occurs when an object with constant velocity changes its direction (happens in a sharp turn, pushes over into a dive, or pulls out of a dive). Angular acceleration occurs when an object both speed and direction change simultaneously (happens in spins and climbing turns) [38]. The tolerance of the force $G$ depends on the acceleration axis, the magnitude of the acceleration, the initial velocity of the acceleration, the duration of action, and the position of the body. It is difficult to determine the G-force tolerance. Because G-force tolerance may change among individuals and fluctuate from day to day for the same person [39]. The effects of G-forces on the human body are shown in Fig. 7.

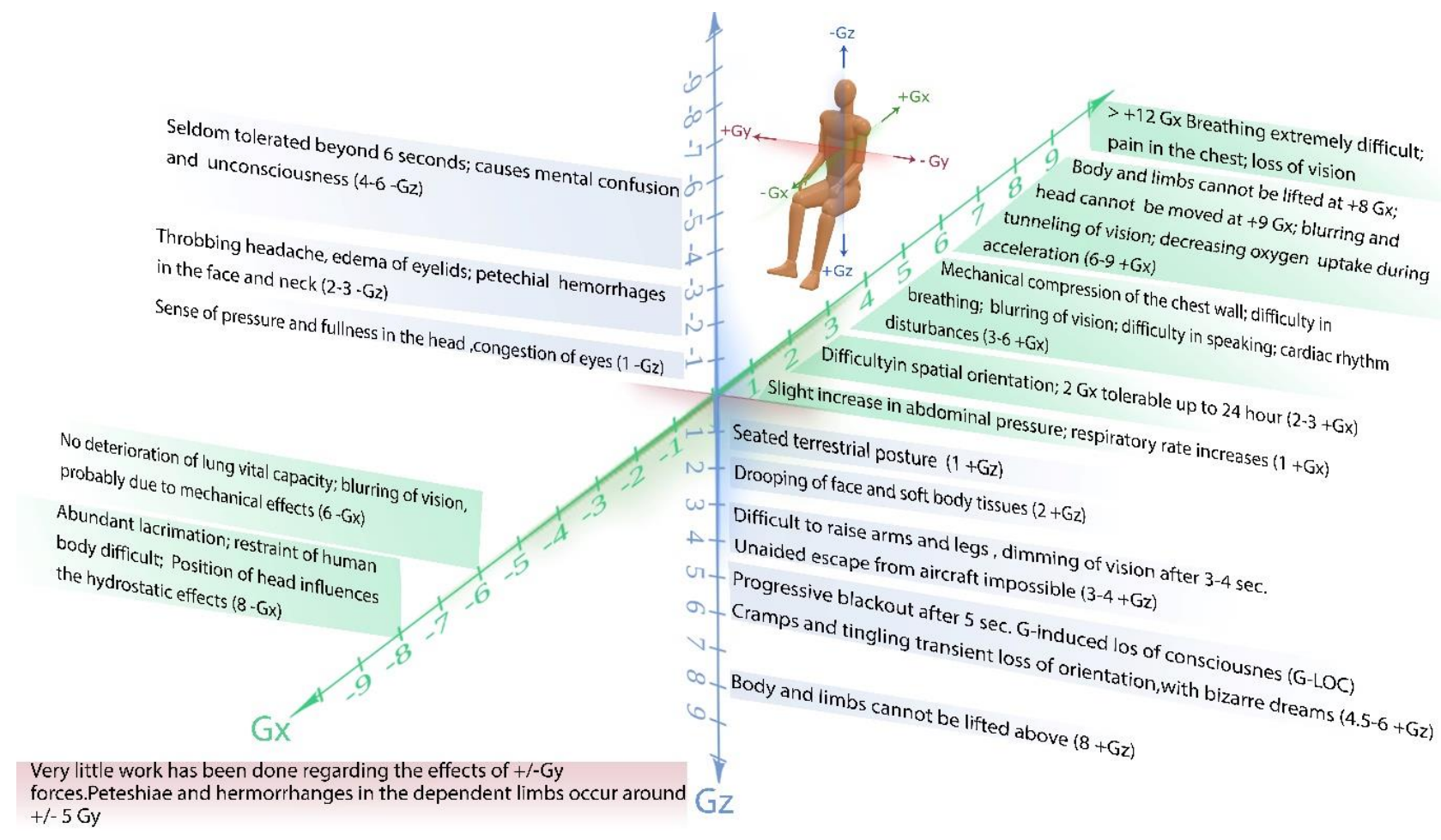

Fig. 7. The effects of G-forces on the human body 
The G-force is seen in the Gx and Gy direction on highways and railways. The G-forces generated by the movement of vehicles on highways and railways are not fatal as long as there is no collision and prolonged exposure. The maximum braking acceleration that can be tolerated is $20 \mathrm{~g}$ for adult humans (for a short time). In terms of safety, $0.32 \mathrm{~g}$ braking acceleration is recommended for road vehicles, and over $0.32 \mathrm{~g}$ is disturbing. However, studies have shown that drivers decelerate above $4.5 \mathrm{~m} / \mathrm{s}^{2}$ at a sudden obstacle and $90 \%$ of them deceleration above $3.4 \mathrm{~m} / \mathrm{s}^{2}$. These values are accelerations that can be stopped without losing control of the steering in its lane on wet surfaces [40].

While take off in a conventional aircraft will produce some increase in $+\mathrm{Gx}$, and landing may give rise to -Gx. However, it is seen that the tolerance of the human body in the Gz direction is low in Figure 8. In civilian commercial flying operations, pilot exposure to excessive $\mathrm{G}$ force is not encountered during normal flight, with any exception, for example during turbulence, in moderate to severe turbulence, $g$ loading may occur in less than 0.5 seconds. $G$ levels in commercial airline operations tend to be relatively constant around a narrow range centered on $+1 \mathrm{Gz}$ and very rarely exceed $+2 \mathrm{Gz}$. No circumstance was found of exposure to more than $+2.7 \mathrm{Gz}$. In normal flight, -0.5 to $+1.5 \mathrm{Gz}$ is typical and the upper level is rarely exceeded even with tight radius turns in police or survey aircraft. There have not been any cases of such as causes of ALOC or G-LOC in general or commercial aviation in 'more than 25 years' [of experience]. Avoiding the harmful effects of g-force in aviation depends on the skill and training of the pilots [41].

The maximum acceleration of the commercial Maglev trains is $0.16 \mathrm{~g}$ (16 $\mathrm{m} / \mathrm{s} 2)$ and the maximum jerk is $0.25 \mathrm{~g}(2.5 \mathrm{~m} / \mathrm{s} 3)$ [42].

It is stated that $1 \mathrm{~g}$ force will not be exceeded during the travel in Hyperloop Alpha. The comfort acceleration for Hyperloop was stated as $0.5 \mathrm{~g}$ in various studies. It was determined that the acceptability criteria that 95 percent of passengers will not hesitate to travel again are lower values than $0.3 \mathrm{~g}$ for positive vertical acceleration and $0.2 \mathrm{~g}$ for negative vertical acceleration in a study published by the Volpe Center in 1994. [24].

The Virgin Hyperloop has studies that its model is capable of 4.5 times tighter turning radius, with near-zero lateral acceleration inside the pod [8]. For the Hyperloop, the potential impact of simultaneous g-forces applied to multiple axes will need to be addressed, and these will constrain the final operational parameters of any design [43].

Some experts believe that using this new technology on cargo-type will be safer than testing it on passengers. [24]. For the Hyperloop cargo type, the gforce may be greater, depending on the cargo to be transported. This situation also may cause various geometry standard differences such as minimum horizontal bend radius in cargo type Hyperloop. However, the g-force would still need to be kept under control, as it may also have effects on the Hyperloop infrastructure such as tubes, vacuum seals, supports, and internal rails [43]. 
Maglev, Hyperloop, and an airplane can reach lethal levels of g-force easily because of their high-speed potential. Especially in aviation, the g-force effect is felt more. However, it is also a solvable issue for Hyperloop with correct route geometry and speed planning.

\section{ROUTE AND GEOMETRY}

The speed, capacity, and maximum gradient data of Maglev, Hyperloop, and HSR types were compared in Table 1. Geography and the geometric features of the route are the major factors that increase the cost of earthworks. The idea proposed in Hyperloop Alpha is to move alongside the highway to reduce earthworks between San Francisco and Los Angeles. Considering the restrictive geometric standards of highways (such as small-diameter horizontal curves), it is not possible to use this recommendation in every geography for high-speed trains. The minimum curve radius is effective in limiting the maximum speed on the curve so that the vehicle can move without derailment or damage to the rail [44].

Table 1. Basic specifications HSR, Maglev, Hyperloop [1]

\begin{tabular}{|c|c|c|c|}
\hline- & High-Speed Rail & Maglev & Hyperloop \\
\hline Current max. speed & $\begin{array}{c}380 \mathrm{~km} / \mathrm{h} \\
(236 \mathrm{mph})\end{array}$ & $\begin{array}{c}431 \mathrm{~km} / \mathrm{h}(270 \\
\mathrm{mph})\end{array}$ & $\begin{array}{c}387 \mathrm{~km} / \mathrm{h}(240 \mathrm{mph}) \\
\text { Virgin Hyperloop One }\end{array}$ \\
\hline Speed record & $\begin{array}{c}\text { TGV }(2007) 574.8 \\
\mathrm{~km} / \mathrm{h}(357.2 \mathrm{mph})\end{array}$ & $\begin{array}{c}\text { YMLT }(2015) 603 \\
\mathrm{~km} / \mathrm{h}(375 \mathrm{mph})\end{array}$ & - \\
\hline Max. Design speed & $\begin{array}{c}402 \mathrm{~km} / \mathrm{h}(250 \\
\mathrm{mph})\end{array}$ & $\begin{array}{c}604 \mathrm{~km} / \mathrm{h}(375 \\
\mathrm{mph})\end{array}$ & $\begin{array}{c}1.223 \mathrm{~km} / \mathrm{h}(760 \\
\mathrm{mph})\end{array}$ \\
\hline $\begin{array}{c}\text { Max. Seating } \\
\text { capacity }\end{array}$ & 1500 & 824 & 28 per capsule \\
\hline $\begin{array}{c}\text { Min. Horizontal } \\
\text { curve }\end{array}$ & $7.6 \mathrm{~km}(4.7 \mathrm{miles})$ & $9.1 \mathrm{~km}(5.7 \mathrm{miles})$ & $4.8 \mathrm{~km}(3.0 \mathrm{miles})$ \\
\hline Max. gradient & $4 \%$ & not applicable & not applicable \\
\hline $\begin{array}{c}\text { Technology } \\
\text { maturity }\end{array}$ & mature & almost mature & infant \\
\hline
\end{tabular}

A near-linear route must be preferred to speed up without being affected by $\mathrm{g}$ forces in the Hyperloop route geometry. Geometric constraints are not determined completely for the route in Hyperloop. Since the route specified in Hyperloop Alpha belongs to the highway, the longitudinal gradient of $6 \%$ in Table 1. has been accepted as the maximum longitudinal gradient value described so far for Hyperloop. The maximum longitudinal gradient value is $10 \%$ in Maglev, $4 \%$ on the high-speed train $[45,46]$.

The minimum horizontal curb radius changes according to the speeds of the High-Speed train ICE and Shanghai Maglev are shown in Table 2 [46]. In the Hyperloop studies conducted in the UK, the relationship between speed and 
minimum horizontal curve radius of Hyperloop is shown in Table 3 [43]. Also, it is seen that the minimum radius of Maglev and Hyperloop are very similar in the graphic in Figure 8 [44].

Table 2. Comparison between two German trains of ICE-03 HSR and TR-08 maglev [46]

\begin{tabular}{|l|l|l|}
\hline \multicolumn{1}{|c|}{ Parameter } & $\begin{array}{c}\text { Inter City Express (ICE) 3 ICE-03 } \\
\text { the type series 403 }\end{array}$ & $\begin{array}{c}\text { Transrapid Shanghai } \\
\text { Maglev TR-08 SMT the } \\
\text { type series TR 08 }\end{array}$ \\
\hline $\begin{array}{l}\text { Max. Longitudinal } \\
\text { gradient }\end{array}$ & 3.5 & 10 \\
\hline Max. Side Acceleration & $1 \mathrm{~m} / \mathrm{s}^{2}$ & 705 \\
\hline Speed $(\mathrm{km} / \mathrm{h})$ & Curve Radius $(\mathrm{m})$ & 1100 \\
\hline 200 & 1400 & 1590 \\
\hline 250 & 2250 & 2160 \\
\hline 300 & 3200 & 2825 \\
\hline 350 & - & 3580 \\
\hline 400 & - & \multicolumn{2}{|l|}{} \\
\hline 450 & - &
\end{tabular}

Table 3. Summary Table of Indicative Alignment Minimum Curves based on 0.5 lateral g-forces, not allowing for capsule rotation (cant) [43]

\begin{tabular}{|c|c|}
\hline $\begin{array}{c}\text { Capsule } \\
\text { Velocity km/h } \\
\text { (mph) }\end{array}$ & $\begin{array}{c}\text { Approx. Minimum Tunnel } \\
\text { Alignment Radii (m) (without } \\
\text { can't allowance) }\end{array}$ \\
\hline $160(100)$ & 410 \\
\hline $320(200)$ & 1630 \\
\hline $483(300)$ & 3700 \\
\hline $643(400)$ & 6500 \\
\hline $805(500)$ & 10200 \\
\hline $965(600)$ & 14675 \\
\hline $1125(700)$ & 20000 \\
\hline
\end{tabular}




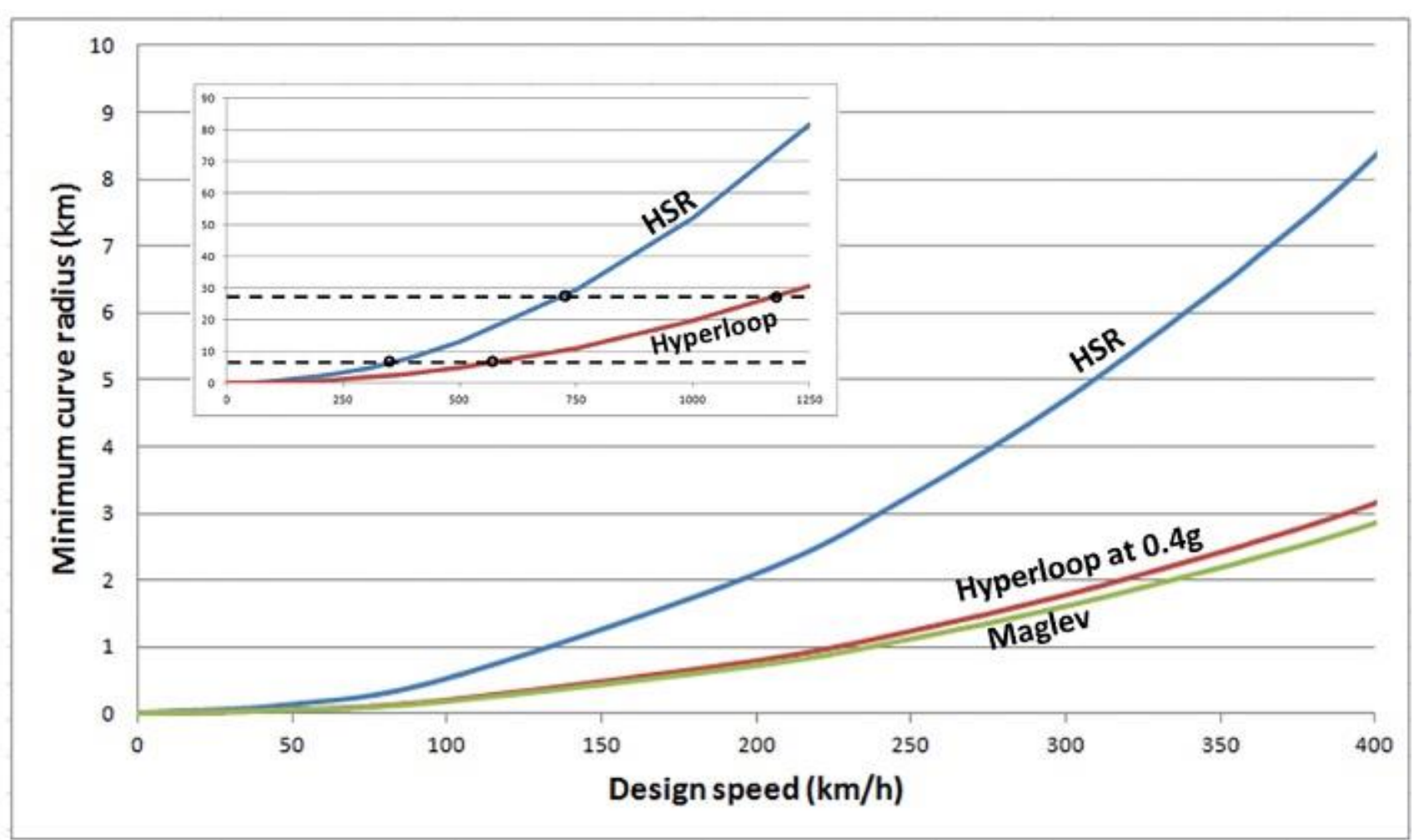

Fig. 8. Estimated minimum horizontal curve radius for HSR, Maglev and Hyperloop [44]

\section{HYPERLOOP COST}

Hyperloop first came out with the claim that it would be faster and less costly than the high-speed train planned to be built between San Francisco and Los Angeles in the United States. Therefore, most studies have been on feasibility and cost for Hyperloop. Because of the Hyperloop system similarity, it is mostly compared to Maglev in terms of cost. Since Hyperloop is not a current application area, the information in this study is included in the reports of the relevant companies and the costs in the places planned to be made because of the agreements with the countries. The costs are divided into three categories: capital, operating, and overhead. The costs of constructing infrastructure (rails, stations) and acquiring vehicles are referred to as capital costs. Operating costs are the costs associated with the maintenance of infrastructure and vehicles and the operation of vehicles and stations [23].

Table 4. Hyperloop Project

\begin{tabular}{|l|l|l|l|}
\hline $\begin{array}{c}\text { Hyperloop } \\
\text { Project }\end{array}$ & \multicolumn{1}{|c|}{ Cost } & $\begin{array}{c}\text { Length } \\
(\mathbf{k m})\end{array}$ & \multicolumn{1}{c|}{ Note } \\
\hline $\begin{array}{l}\text { Los } \\
\text { Angeles- }\end{array}$ & $\begin{array}{l}\text { Hyperloop } \\
\text { Alpha: }\end{array}$ & 563 & $\begin{array}{l}\text { These costs are only the construction costs of the system, } \\
\text { land acquisition and station costs are not included. }\end{array}$ \\
$\begin{array}{l}\text { Fancisco } \\
\text { million [19] }\end{array}$ & $\begin{array}{l}\text { Hyperloop Alpha has estimated the construction costs of } \\
\text { the station at \$125 million. It has been stated that with a } \\
\text { capsule capacity of 28 people, per person ticket prices } \\
\text { will be \$20 [19] }\end{array}$ \\
\hline
\end{tabular}




\begin{tabular}{|l|l|l|l|}
\hline $\begin{array}{l}\text { Hyperloop } \\
\text { Project }\end{array}$ & \multicolumn{1}{|c|}{ Cost } & $\begin{array}{c}\text { Length } \\
\mathbf{k m})\end{array}$ & \multicolumn{1}{c|}{ Note } \\
\hline $\begin{array}{l}\text { Abu Dhabi- } \\
\text { Dubai }\end{array}$ & $\begin{array}{l}\text { \$20-40 } \\
\text { billion per } \\
\text { km [6,7] }\end{array}$ & 150 & $\begin{array}{l}\text { It has been declared that the system will reduce the travel } \\
\text { from approximately 45 minutes to 12 minutes by plane, } \\
\text { and the system is efficient enough to compensate itself } \\
\text { within 8-15 years [6,7] }\end{array}$ \\
\hline $\begin{array}{l}\text { Russian- } \\
\text { China }\end{array}$ & $\begin{array}{l}\text { \$1.5-2.3 } \\
\text { billion [5] }\end{array}$ & 65 & $\begin{array}{l}\text { Annual operating income of \$250 million, operating costs } \\
\text { of \$77 million are estimated. Average speed 540 km/h [5] }\end{array}$ \\
\hline India & $\begin{array}{l}\text { \$10.1 billion } \\
\text { [47] }\end{array}$ & 148 & $\begin{array}{l}\text { It is stated that ticket fares between Mumbai-Pune will } \\
\text { not be more than HSR. (Mumbai- Ahmedabad High- } \\
\text { Speed train ticket would be around ₹3,000 \$40) [8,48] }\end{array}$ \\
\hline Netherlands & $\begin{array}{l}\text { The Netherlands is the country where Hyperloop, which is planned to reach Brussels } \\
\text { in less than 30 minutes from Amsterdam and 90 minutes to Paris, has important } \\
\text { studies and entrepreneurs in Europe [10] }\end{array}$ \\
\hline Poland & $\begin{array}{l}\text { Poland has prepared a long-term project for Hyperloop by gradually improving the } \\
\text { existing infrastructure system [11] }\end{array}$ \\
\hline
\end{tabular}

Information on Hyperloop projects is given in Table 4. However, the same structures built in the same country or different places show the difference in cost and requirement because of their geographical features. The rough terrain between Russia and China, the desert floor between Abu Dhabi and Dubai, will cause additional costs. System costs alone outside of the land will vary depending on the company implementing the project. There are additional costs in the Hyperloop cargo type. When carrying big bulk goods that are not time-sensitive, freight train offers an advantage, so Hyperloop is unlikely to have a substantial impact on rail market share. Hyperloop cargo version would probably be similar to the aircraft cargo system. Airfreight is currently costly, and it is only utilized for time-sensitive, high-value, or perishable cargo. Furthermore, creating a similar hub-and-spoke system with the same geographic reach as the air network would necessitate a massive expenditure [24].

As a result of NASA's feasibility, energy and ticket pricing per person in Hyperloop are shown in Table 5 [25]. According to Table 5, the needed energy has increased with the passenger capacity, but the ticket cost per person has decreased. Considering that there are 28 people in a capsule, the approximate cost per person is slightly less than $\$ 76$. According to these values, it is seen that a capacity of 100 people in a capsule is needed for the \$20 ticket fee mentioned in the Hyperloop Alpha.

Table 5. Energy and ticket cost per person in Hyperloop [25]

\begin{tabular}{|c|l|l|l|l|l|l|l|l|l|l|}
\hline $\begin{array}{c}\text { Passenger per } \\
\text { pod }\end{array}$ & 10 & 20 & 30 & 40 & 50 & 60 & 70 & 80 & 90 & 100 \\
\hline $\begin{array}{c}\text { Energy Cost } \\
\mathbf{( \$ M )}\end{array}$ & 28.2 & 28.6 & 29 & 29.5 & 29.9 & 30.3 & 30.7 & 31.1 & 31.6 & 32 \\
\hline $\begin{array}{c}\text { Total } \\
\text { \$Passenger }\end{array}$ & 226 & 113 & 76 & 57 & 45 & 38 & 33 & 29 & 25 & 23 \\
\hline
\end{tabular}


Station construction costs were estimated at $\$ 125$ million for Hyperloop Alpha. Station locations planned in Hyperloop Alpha are outside of the city in both San Francisco and Los Angeles. Station construction is more costly in an urban location, and being outside of the city will cause a different means of transportation to get to the station and indirectly a waste of energy and time. The addition of intermediate stations and branches will have a cost-increasing effect. Even if it is aimed to reduce the excavation operations thanks to the positioning of the poles at the desired height on the route, the land prices may be much higher than expected and soil improvements may be required [24].

Costs for two stations of the current Maglev line near Shanghai are \$1.33 to $\$ 1.2$ billion, which is $\$ 130$ million for these two stations significantly less than Musk's mention for the Hyperloop. However, Hyperloop stations are more complex than Maglev stations because access must be given to vehicles in evacuated tubes [23].

The operating cost at the station is also not specified in Hyperloop Alpha. Although the Hyperloop Alpha proposal defines an electronic ticketing system that will eliminate the human factor in ticketing, it is likely that personnel will be needed in services such as station capsule maintenance or cleaning, security, customer service, and customer baggage assistance [24].

Station operating costs should be added to the total cost, but the need for personnel, labor, etc. in operating costs is also in question in Maglev and air transportation. The special technical requirements in the Hyperloop station, which is different from other transportation modes, is the most important reason that increases the cost.

\section{MAGLEV COST}

According to the United States Railway Administration in 2005; While the construction cost of the one-kilometer Maglev train line varies between $\$ 31.25$ million and $\$ 62.50$ million, the benefit of Maglev trains becomes even more clear with the ideal travel length of over 240 kilometers [49]. The lengths and costs of existing Maglev lines in China, Japan, and South Korea are shown in Table 6. Estimated project costs according to routes planned for Hyperloop and costs of existing Maglev systems are shown in this study. However, building the same system in a different location in the same country has different costs due to geographical conditions. Therefore, competitive distances that provide maximum benefit in transportation, which is a requirement of feasibility, are shown in Figure 9 [49,50]. 
Table 6. Maglev lines and their costs [51]

\begin{tabular}{|c|c|c|c|c|c|}
\hline $\begin{array}{l}\text { Maglev } \\
\text { Project } \\
\text { (Year of } \\
\text { Cost) }\end{array}$ & Country & $\begin{array}{l}\text { Total Project Cost } \\
\text { Including Trains } \\
(\$)\end{array}$ & $\begin{array}{l}2016 \text { Costs with } \\
\text { CPI Inflation (\$) }\end{array}$ & $\begin{array}{l}\text { Length } \\
\text { (miles) }\end{array}$ & $\begin{array}{l}\text { Project Cost } \\
\text { Per Mile (\$) }\end{array}$ \\
\hline $\begin{array}{l}\text { Shanghai } \\
(2004)\end{array}$ & China & $\$ 1,580,000,000$ & $\$ 2,021,873,054$ & 18.6 & $\$ 108,700,000$ \\
\hline $\begin{array}{l}\text { Linimo } \\
(2005)\end{array}$ & Japan & $\$ 922,000,000$ & $\$ 1,141,188,623$ & 5.5 & $\$ 207,500,000$ \\
\hline $\begin{array}{c}\text { Incheon } \\
\text { Airport } \\
(2012) \\
\end{array}$ & $\begin{array}{l}\text { South } \\
\text { Korea }\end{array}$ & $\$ 342,000,000$ & $\$ 360,076,126$ & 3.8 & $\$ 94,700,000$ \\
\hline $\begin{array}{c}\text { Changsha } \\
(2016)\end{array}$ & China & $\$ 674,000,000$ & $\$ 674,000,000$ & 11.5 & $\$ 58,600,000$ \\
\hline $\begin{array}{c}\text { Chuo } \\
\text { Shinkansen } \\
(2016)\end{array}$ & Japan & $\$ 90,000,000,000$ & $\$ 90,000,000,000$ & 310.7 & $\$ 289,700,000$ \\
\hline $\begin{array}{c}\text { Skytran } \\
(2016)\end{array}$ & Israel & N/A & N/A & N/A & $\$ 13,000,000$ \\
\hline $\begin{array}{c}\text { Baltimore } \\
\text { Washington } \\
\text { DC }(2016)\end{array}$ & USA & $\$ 12,000,000,000$ & $\$ 12,000,000,000$ & 40 & $\$ 300,000,000$ \\
\hline $\begin{array}{l}\text { U.S. Maglev } \\
\text { Network } \\
(2013)\end{array}$ & USA & $\$ 970,000,000,000^{15}$ & $\$ 999,355,000,000$ & 29,000 & $\$ 34,500,000$ \\
\hline
\end{tabular}

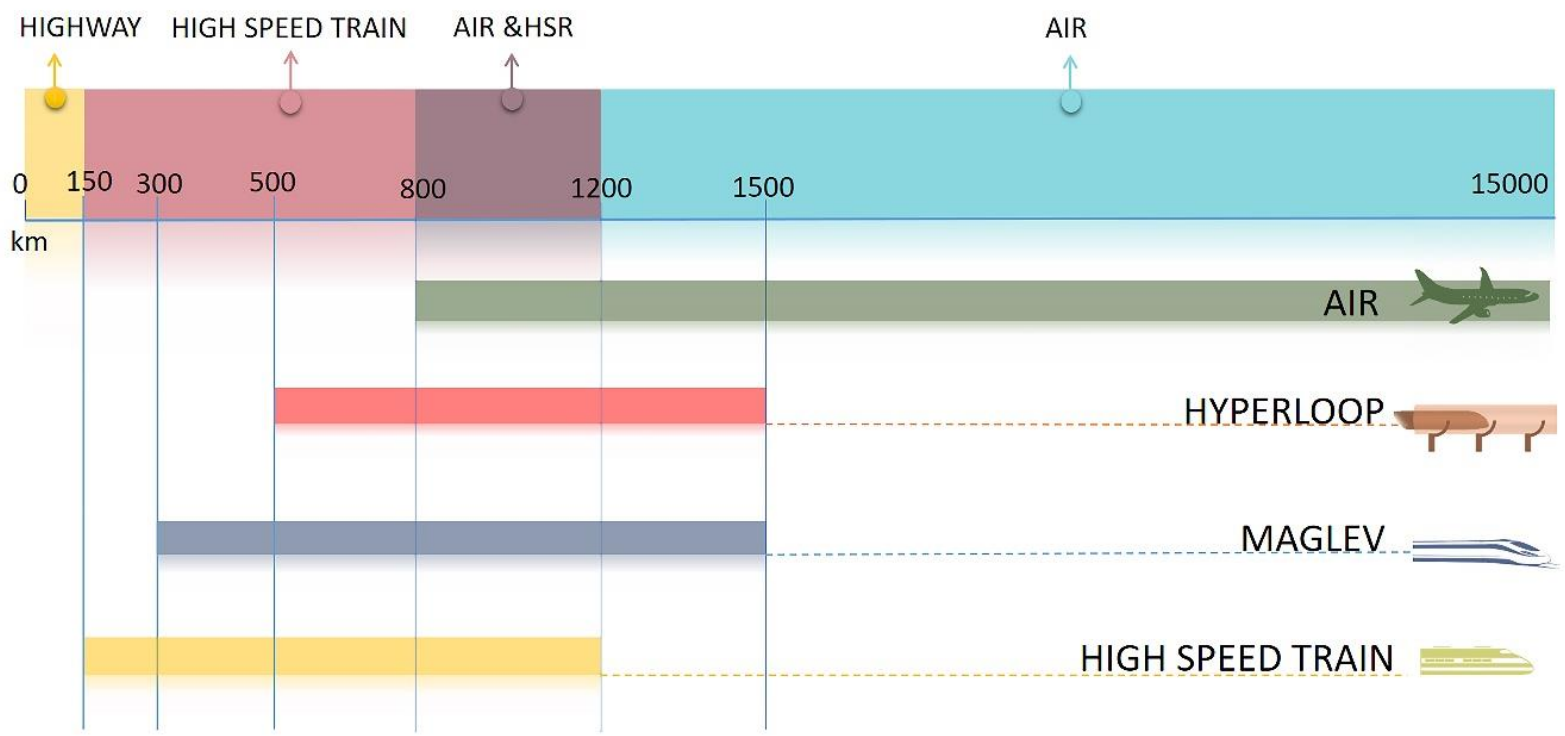

Fig. 9. Competitive travel distance for Maglev, Hyperloop, High-Speed Train and Airplane (not scale) 


\section{CONCLUSION}

The advantages and disadvantages of Hyperloop and other vehicles have been revealed under security and cost issues by comparing them. The Hyperloop will be costlier because of its additional requirements (vacuum pump, tube, etc.) of the Maglev system under the same conditions. However, the high estimated cost of construction will be reflected in passenger fees. When these fees are distributed to 28 people traveling in a capsule, the high cost will prevent the spread of this system and serve the society whose income is above a certain level. However, Hyperloop's attractive features, such as high speed, utilization of solar energy, and weather resistance, can make it a means of transportation to operate in certain places, despite its cost. Although Concorde was the most expensive and the fastest aircraft in the past, the reason it went out of use was not its cost but the accidents and political crises of the period [52]. In this respect, cargo transportation at the first stage may be an effective solution to increase and prove the reliability of Hyperloop. With the development of technology, when experience is gained about more economical solutions, designs and managerial or engineering deficiencies that may arise in the cargo type Hyperloop installed before, the passenger type Hyperloop application may be more acceptable in the community with reliability and cost. Hyper Poland company mentioned that the standard of Hyperloop infrastructure should be the same in every country, and the companies interested in this issue should reach a consensus. This suggestion can be useful in terms of increasing the widespread and applicability of Hyperloop. However, as in the history of the Maglev train, technological competition in the world may prevent the implementation of this idea.

\section{ACKNOWLEDGMENT}

The authors declared no conflicts of interest with respect to the research, authorship, and/or publication of this article. The authors also declared that this article is original, was prepared in accordance with international publication and research ethics, and ethical committee permission.

\section{References}

1. Gieras J. Ultra high-speed ground transportation systems: Current Status and a vision for the future. Przeglad Elektrotechniczny. 2020;1(9):3-9. doi:10.15199/48.2020.09.01

2. Garfield L. 15 remarkable images that show the 200-year evolution of the Hyperloop. Business Insider. 2018 Feb 21; [cited 2020 May 1]. Available at: https://www.businessinsider.com.au/ .

3. Buitendijk M. Marin Tests First Transatlantic Underwater Hyperloop. SWZ MARITIME. 2019 Sep 10; [cited 2021 Jan 13]. Available at: https://www.swzmaritime.nl/ . 
4. Thompson PJ. A Scientific and Economic Analysis of the Hyperloop as it Pertains to Mass Transportation. Case Western Reserve University; 2019. [cited 2020 Sep 10]. Available at: https://etd.ohiolink.edu/ .

5. Upbin B. Hyperloop on the Silk Road Shuttling Cargo Between Russia and China at $540 \mathrm{~km} / \mathrm{h}$. REconnecting Asia. 2017 Jan 31. [cited 2020 Apr 10]. Available at: https://reconnectingasia.csis.org/ .

6. Khaleej Times. Dubai-Abu Dhabi 12-minute Hyperloop by 2020. Khaleej Times. 2019 Jan 17. [cited 2020 March 15]. Available at:https://www.khaleejtimes.com/ .

7. Arabian Business. UAE's Hyperloop System to Cost up to $\$ 40 \mathrm{~m}$ per $\mathrm{km}$. ArabianBusiness. 2017. [updated 2017 Jan 17;cited 2020 Mar 15]. Available at: https://www.arabianbusiness.com/ .

8. Singh J. Is India Ready for Hyperloop? An Engineer Who Rode It First, Says Yes. Gadgets-360. 2021. [updated 2020 Dec 9; cited 2020 Dec 20]. Available at: https://gadgets.ndtv.com/ .

9. CNBC-TV18. Hyperloop in Mumbai-Pune, Bengaluru may be ready by 2029, says Virgin Hyperloop One. 2020. [updated 2020 Oct 30;cited 2021 Jan 30]. Available at: https://www.cnbctv18.com/ .

10. Boffey D. Amsterdam to Paris in 90 minutes? . The Guardian. 2020 Apr 10. [cited 2020 Sep 25]. Available at:. https://www.theguardian.com/international .

11. Kennedy C. Future of Rail/ Poland's First Step to Hyperloop High Speed Transport. New Civil Engineer. 2020 Jun 19. [cited 2020 Oct 25]. Available at: https://www.newcivilengineer.com/ .

12. González E, Nogués S. Railways Of The Future: Evolution And Prospects Of Highspeed Rail, Maglev And Hyperloop (1st Part) . DYNA INGENIERIA E INDUSTRIA. 2017;92(4):371-373. doi: http://dx.doi.org/10.6036/8269 .

13. HNTB, PBSJ\&, SANDAG. SANDAG Maglev Study Phase 1 Final Report. 2016:185. [cited 2021 Feb 19]. Available at: https://www.sandag.org/ .

14. Yadav M, Mehta N, Gupta A, Chaudhary A, Mahindru DV. Review of Magnetic Levitation (MAGLEV): A Technology to Propel Vehicles with Magnets. Global Journal of Researches in Engineering Mechanical \& Mechanics. 2013;13(7)

15. BBC. The Magnetic Attraction Of Trains. BBC. 1999 Nov 9. [cited 2021 May 13]. Available at: http://news.bbc.co.uk/2/hi/science/nature/488394.stm .

16. Raheel A, Jun YL, Azhar MF, Junejo NUR. Comprehensive Study and Review on Maglev Train System. Applied Mechanics and Materials. 2014;615:347-351 doi: https://doi.org/10.4028/www.scientific.net/amm.615.347 .

17. Prasad N, Jain S, Gupta S. Electrical Components of Maglev Systems: Emerging Trends. Urban Rail Transit 2019;5:67-79. doi:https://doi.org/10.1007/s40864-0190104-1.

18. Lee HW, Kim KC, Lee J. Review of Maglev Train Technologies. IEEE Transactions On Magnetics. 2006;42(7):1917-1925. doi: https://doi.org/10.1109/TMAG.2006.875842 .

19. Musk E. Hyperloop Alpha SpaceX. 2013. [cited 2019 Nov 12]. Available at: https://www.tesla.com/sites/default/files/blog_images/hyperloop-alpha.pdf .

20. Ammori M, Benkler Y. Hyperloop Law: Autonomy, Infrastructure And Transport Startups. Berkman Klein Center for Internet \& Society at Harvard University and Harvard Journal of Law \& Technology. 2017. [cited 2020 July 18]. Available at: https://cyber.harvard.edu/ .

21. Delft Hyperloop. Levitation Systems for the Hyperloop. Hyperloop Connected 2019. [cited 2020 Apr 28]. Available at:https://hyperloopconnected.org/ . 
22. Cassandra. How Does Hyperloop Work? Everything You Need To Know About Magnetic Levitation. alphr. 2020. [cited 2021 Jan 10]. Available at: https://www.alphr.com/ .

23. Goeverden K v, Milakis D, Janic M, Konings R. Performances of the HL (Hyperloop) transport system. 2017:29-43. Towards an Autonomous and Interconnected Transport Future. [cited 2020 June 10]. Available at: https://repository.tudelft.nl/islandora/object/uuid\%3A7dc4b712-f8f8-49f4-ac93cc0003283b72.

24. Catherine L. Taylor DJH, Lawrence C. Barr. HyperloopCommercial Feasibility Analysis: High Level Overview. Library NT; 2016:47. [cited 2021 Jan 19]. Available at: https://rosap.ntl.bts.gov/view/dot/12308 .

25. Decker K, Chin J, Peng A, et al. Conceptual Feasibility Study of the Hyperloop Vehicle for Next-Generation Transport. 2017:22. Available at: https://ntrs.nasa.gov/citations/20170001624 .

26. Tarver WJ, Volner K, Cooper. JS. Aerospace Pressure Effectss. StatPearls. StatPearls Publishing; 2021. [cited 2021 Feb 1]. Available from: https://www.ncbi.nlm.nih.gov/books/NBK470190/ .

27. Stull R. Altitude and Pilot Physiology. The University of British Columbia. 2021. [updated 2020 May ;cited 2021 Dec 3]. Available at: https://www.eoas.ubc.ca/ .

28. Santangelo A. Hyperloop As An Evolution Of Maglev. Transportation Systems And Technology. 2018;4:44-63. doi:http://doi.org/10.17816/transsyst20184444-63 .

29. Railway Technology. How Japan's Rail Network Survived the Earthquake. Railway Technology. 2011. [updated 2011 Jun 27 ; cited 2021 Feb 25]. Available at: https://www.railway-technology.com/ .

30. Yoshimitsu S, Eiichi N, Toshikazu D. Lessons from the Great Hanshin Earthquake. Creates-Kamogawa Publishers 2005. [cited 2021 Mar 12]. Available at: http://www.shinsaiken.jp/oldweb/hrc-e/publish/lessons_ghe/ .

31. Suzuki H. Research Trends on Riding Comfort Evaluation in Japan. Proceedings of the Institution of Mechanical Engineers Part F: Journal of Rail and Rapid Transit. 1998;212(1) ( Part F: Journal of Rail and Rapid Transit):61-72. doi:10.1243/0954409981530689

32. Kim Y-G, Kwon H-B, Kim S-W, Kim C-K, Kim T-W. Correlation of ride comfort evaluation methods for railway vehicles. Proceedings of the Institution of Mechanical Engineers, Part F: Journal of Rail and Rapid Transit. 2003;217(2):73-88. doi:10.1243/095440903765762823

33. Samah AAA. Whole Body Vibration Analysis for Ride Quality of LRT Passenger. Batu Pahat: Universiti Tun Hussein Onn Malaysia; 2016. Available at: https://core.ac.uk/download/pdf/83541259.pdf .

34. Street F. How long until Hyperloop is here? CNN. [updated 2019 Dec 10;cited 2021 Feb 10]. Available at: https://edition.cnn.com/travel .

35. Stump J. The Need For Speed - And Science: Virgin Hyperloop To Benefit From WVU Neuroscientists' Expertise On Brain, Body İmpacts. WVUTODAY. 2020. [cited 2021 Feb 18]. Available at: https://wvutoday.wvu.edu/ .

36. Alsammarae R. Virgin Hyperloop One and BIG Reveal Videos Showing Hyperloop's 'Zoetrope' Windows. Middleeast Architect. 2018. [cited 2020 Mar 15]. Available at: https://www.middleeastarchitect.com/ .

37. Bell K. Hyperloop CEO Shows Off Augmented Reality Window Concept. Mashable. 2016. [cited 2021 Jan 1]. Available at: https://mashable.com/_. 
38. Wyrick B.C, Brown J.R, Acceleration in Aviation: G-Force. FAA Civil Aerospace Medical Institute. (Administration United States Department of Transportation). [cited 2020 Mar 15].Available at: https://www.faa.gov/pilots/safety/pilotsafetybrochures/media/acceleration.pdf .

39. Kumar KV, Norfleet WT. Issues on Human Acceleration Tolerance After LongDuration Space Flights. 1992:58. [cited 2021 Feb 5]. Available at: https://ntrs.nasa.gov/citations/19930020462 .

40. Kumaş H, Gencer C, Maraş H. Ağır Araçlar İçin Yol Eğimi Ve Viraj Yarıçapı Dikkate Alınarak En Hızlı Güzergâhın Belirlenmesi. Journal of the Faculty of Engineering and Architecture of Gazi University. 2012 2011;27:385-395.

41. Evans S. Enquiry into the Risk of Cognitive Impairment Due to G Forces. UK Civil Aviation Authority; 2020. p. 182. [cited 2021 Mar 20] Available at: https://www.caa.co.uk/home/ .

42. General Atomics Low Speed Maglev Technology Development Program (Supplemental \#3)Final Report. U.S. Department of Transportation. (Federal Transit Administration ) 174 (2005). [cited 2020 Sep 16]. Available at: https://www.transit.dot.gov/ .

43. London Bridge Associates Ltd, British Tunnelling Society. BTS Hyperloop Challenge: Tunnels for Hyperloop 2019:121. [cited 2020 Mar 27]. Available at: https://britishtunnelling.com/ .

44. Taylor N. B, Supplementary Information for Comparative Analysis of Transport Modes. Proceedings of the Institution of Civil Engineers - Transport. ICE Publishing [cited 2020 Mar 30]; doi: https://doi.org/10.1680/jtran.18.00150 .

45. SIEMENS. Shanghai Maglev Transrapid Technology. SIEMENS. 2006. [cited 2021 Jan 1]. Available at: https://www.ft.dk/ .

46. Yaghoubi H, Barazi N, Aoliaei MR. Maglev. In: Perpinya DX, ed. Infrastructure Design, Signalling and Security in Railway. In Tech; 2012:123-176:chap Maglev. doi: 10.5772/35339 Available at: https://www.intechopen.com/chapters/34787 .

47. Jadhav R, Reuters Staff. India Grants Infrastructure Project Status to \$10-Billion Hyperloop Plan. Reuters. 2019. [updated 2019 Aug 1;cited 2020 March 6]. Available at: https://www.reuters.com/ .

48. Mint. Mumbai-Ahmedabad bullet train fare to be around ₹3,000. mint. [updated 2019 Sep 12 ;cited 2021 Jan 1]. Available at: https://www.livemint.com/ .

49. Çodur MY. Türkiye'de Maglev Trenlerinin Uygulanabilirliğinin Araştırılması. I Ĭgdır Üniversitesi Fen Bilimleri Enstitüsü Dergisi. 2017;7(1):207-215. doi: https://doi.org/10.21597/jist.2017127433 .

50. Lawrence M, Bullock R, Liu Z. Group WB, ed. China's High-Speed Rail Development. International Development in Focus;. Washington, DC: World Bank. 2019:101. [cited 2021 Jan 20] Available at: http://documents1.worldbank.org/curated/en/933411559841476316/pdf/Chinas-HighSpeed-Rail-Development.pdf .

51. Dona S, Singh A. The Workings Of Maglev: A New Way To Travel. 2017. [cited 2021 Feb 20]. Available at: http://www.cee.hawaii.edu/wp-content/uploads/2016/05/UHMCEE-17-01.pdf .

52. Razi K, Wu N, Wang C, et al. Consumer Desirability of the Proposed Hyperloop. University of California. 2018. [cited 2020 Apr 23]. Available at: https://escholarship.org/uc/item/3w5414sm 
Information about the authors:

\section{Rümeysa ÖZBEK}

ORCID: 0000-0003-1110-3710;

E-mail: rumeysa.ozbek08@erzurum.edu.tr

\section{Muhammed Yasin ÇODUR}

Scopus ID: 29667475400; ORCID: 0000-0001-7647-2424; ResearcherID: A-6290-2013;

E-mail: mycodur@erzurum.edu.tr

\section{To cite this article:}

Özbek R, Çodur MY. Comparison of Hyperloop and Existing Transport Vehicles in Terms of Security and Costs. Modern Transportation Systems and Technologies. 2021;7(3):5-29. doi: 10.17816/transsyst2021735-29 